\title{
4H leukodystrophy
}

\section{Mild clinical phenotype and comorbidity with multiple sclerosis}

\author{
Stephanie M. DeGasperis, MSc, Geneviève Bernard, MD, Nicole I. Wolf, MD, PhD, Elka Miller, MD, and \\ Daniela Pohl, MD, PhD
}

Neurol Genet 2020;6:e409. doi:10.1212/NXG.0000000000000409

Hypomyelinating leukodystrophy with hypodontia and hypogonadotropic hypogonadism (4H leukodystrophy), also known as POLR3-related leukodystrophy, is a genetic disorder caused by autosomal recessive mutations in the POLR3A, POLR3B, POLR1C, or POLR3K genes. ${ }^{1-3}$ Most patients have progressive motor deficits. ${ }^{4}$ We present 2 siblings with a milder phenotype and lack of disease progression previously reported within a larger cohort of patients. $^{5}$

\section{Case presentation}

\section{Case 1}

A 16-year-old previously healthy girl was referred to our neurology clinic with a 3-week history of numbness in her lower extremities, headaches, and blurred vision in her right eye. On examination, she had ataxic gait because of decreased sensation to touch in her lower extremities and hyperreflexia. MRI showed enhancement of the right optic nerve, diffuse symmetric signal abnormalities in the white matter of both cerebral hemispheres, and multiple spinal cord lesions (figure). The CSF analysis revealed oligoclonal bands. She was diagnosed with right optic neuritis and a hypomyelinating leukodystrophy.

She experienced 3 demyelinating relapses. The first occurred 1 month after her initial visit and presented as left optic neuritis. She was treated with monthly IV immunoglobulin for 18 months. At age 18 years, she experienced her second relapse with leg weakness and fatigue. MRI revealed new hyperintense lesions in brain areas and the spinal cord that were not present 7 months before (figure). Her care was transferred to adult neurology. She was diagnosed with multiple sclerosis (MS) and treatment with interferon- $\beta$-1a was initiated. Her third relapse, at age 21 years, again involved bilateral leg weakness. A repeat MRI showed no progression of her disease.

At age 21 years, genetic testing revealed that she was homozygous for the POLR3B pathogenic variant V523E, and she was diagnosed with $4 \mathrm{H}$ leukodystrophy. The patient continued to have no clinical symptoms of $4 \mathrm{H}$ leukodystrophy other than myopia. Her neurologic examination and cognition were normal. She reported suffering from some anxiety and depression.

At the last clinical follow-up at age 26 years, she worked a full-time job. In view of her mood disorder, she had been switched to an immunomodulatory treatment with glatiramer acetate. She had not experienced any progression of her symptoms and had no additional MS relapses.

\author{
Correspondence \\ Dr. Pohl \\ dpohl@cheo.on.ca
}




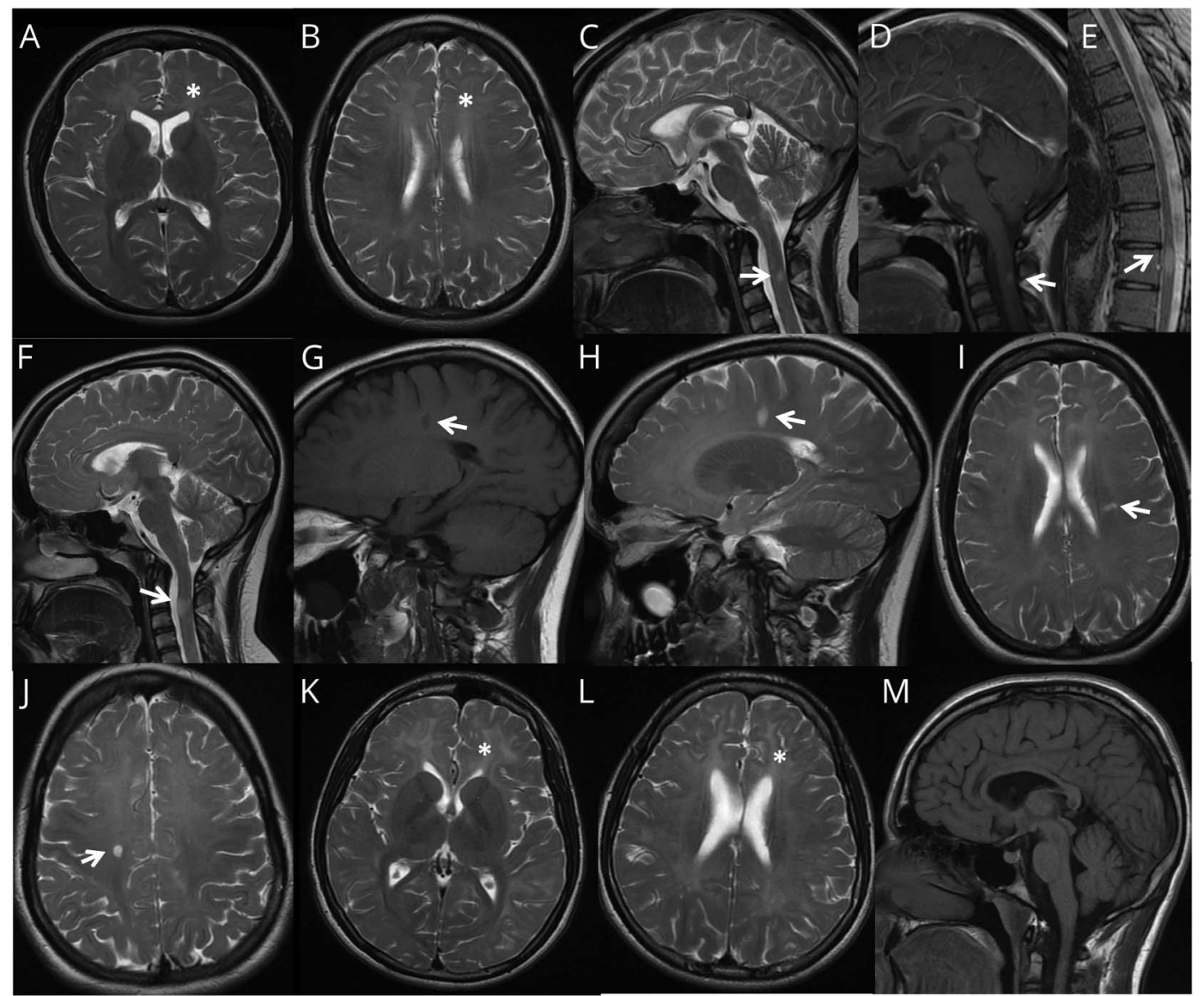

Patient 1 (A-J): MRI at 16 years of age (A-E). Axial T2 ( $A$ and B), sagittal T2 ( $C$ and E), and sagittal T1 with contrast (D). Images demonstrate T2 hyperintensity of the white matter in keeping with hypomyelination ( $*$ in $A$ and $B$ ) with relative preservation of myelin in the anterior limb of the internal capsules, the corpus callosum, optic radiations (A), corticospinal tracts up to the apex (B). Demyelinating lesions within the spinal cord (C-E). MRI at 18 years of age (F-J). Sagittal T2 (F), sagittal T1 without contrast (G), sagittal T2 (H), and axial T2 (I and J). Enlargement of the spinal cord lesion (arrow in F). T1 hypointense and T2 hyperintense oval white matter lesion (arrows in $\mathrm{G}$ and $\mathrm{H}$ ), along the path of the deep medullary vein (Dawson finger, arrows in $\mathrm{H}$ and I). Ovoid lesion of the right centrum semiovale (arrow in J). The corpus callosum is thin (F). Patient 2 (K-M): MRI at 16 years of age. Axial T2 (K and L) and sagittal T1 (M). Hypomyelination (* in K and $\mathrm{L}$ ) and less residual myelin compared with patient 1 , but more residual myelin than is typically seen in $4 \mathrm{H}$ leukodystrophy. No white matter lesions in the brain or spinal cord (M). The corpus callosum is thin (M).

\section{Case 2}

The younger brother of the first patient was referred to the neurology clinic at age 15 years after his first focal-to-bilateral tonic-clonic seizure. His medical history was unremarkable, apart from a learning disability diagnosed at age 11 years. His neurologic examination was normal with the exception of some stumbling on tandem gait testing and myopia. His EEG showed evidence of epileptiform discharges predominantly in the left posterior region and intermittently slow background activity.

At age 16 years, he had a second presumably bilateral tonicclonic seizure (unwitnessed, parents found him postictal) and was administered carbamazepine. His MRI showed bilateral diffuse, symmetric signal changes in the white matter compatible with hypomyelination, thinning of the corpus callosum, and normal myelination of the spinal cord (figure).

At age 18 years, the diagnosis of $4 \mathrm{H}$ leukodystrophy was confirmed with genetic testing. The same V523E mutation as in his sister was also found in his consanguineous parents who were heterozygous carriers. Both parents had short stature but were otherwise asymptomatic with normal dentition, endocrine, cognition and neurologic status. The MRIs of both parents were normal.

Repeat MRI of the patient 1 year after his first presentation was unchanged. He had no neurologic complaints. On examination, he had abnormal upgaze saccades, hyperreflexia in the lower extremities $(3+)$, and mild dysmetria with heel-to-shin testing.

On his last follow-up, the patient was 23 years old. He had remained seizure free on carbamazepine for 5 years and did not have new neurologic deficits.

\section{Discussion}

The patients discussed have atypical presentations of $4 \mathrm{H}$ leukodystrophy. Most reported patients with $4 \mathrm{H}$ 
leukodystrophy have progressive neurologic deficits, with or without dental abnormalities, endocrine problems, and/or myopia. ${ }^{2,5,6}$ Typical clinical presentations range from early childhood motor clumsiness to cognitive difficulties apparent from later childhood. ${ }^{2,5,6}$ Patients' brain MRIs show diffuse hypomyelination with relative preservation of specific structures. Our patients have significantly more residual myelin (figure). Patients with POLR3B mutations typically present slightly earlier but have a milder disease course than those with POLR3A mutations. ${ }^{5,7}$ It is unusual for a $4 \mathrm{H}$ leukodystrophy patient to have absent neurologic deficits by age 26 years.

It is common for patients to have one copy of the V523E mutation in the POLR3B gene; however, homozygosity is rare. We hypothesize that patients carrying 2 copies of this variant are either normal their entire life or have only mild neurologic deficits and therefore do not seek medical attention. Because no other patient with comorbidity of MS and $4 \mathrm{H}$ leukodystrophy has been described, we hypothesize that it is coincidental in our patient.

\section{Study funding}

No targeted funding reported.

\section{Disclosure}

Disclosures available: Neurology.org/NG.

\section{Publication history}

Received by Neurology: Genetics June 25, 2019. Accepted in final form December 18, 2019.

\section{Appendix Authors}

\begin{tabular}{lll}
\hline Name & Location & Contribution \\
\hline $\begin{array}{l}\text { Stephanie M. } \\
\text { DeGasperis, } \\
\text { MSc }\end{array}$ & $\begin{array}{l}\text { University of Ottawa, } \\
\text { ON, Canada }\end{array}$ & $\begin{array}{l}\text { Analyzed the data; drafted } \\
\text { the manuscript for } \\
\text { intellectual content }\end{array}$ \\
\hline $\begin{array}{l}\text { Geneviève } \\
\text { Bernard, MD }\end{array}$ & $\begin{array}{l}\text { McGill University, } \\
\text { Montreal, Quebec, }\end{array}$ & $\begin{array}{l}\text { Revised the manuscript for } \\
\text { intellectual content }\end{array}$ \\
\hline $\begin{array}{l}\text { Elka Miller, } \\
\text { MD }\end{array}$ & $\begin{array}{l}\text { CHEO, University of } \\
\text { Ottawa, ON, Canada }\end{array}$ & $\begin{array}{l}\text { Interpreted the data; revised } \\
\text { the manuscript for } \\
\text { intellectual content }\end{array}$ \\
\hline $\begin{array}{l}\text { Nicole I. Wolf, } \\
\text { MD, PhD }\end{array}$ & $\begin{array}{l}\text { Emma Children's } \\
\text { Hospital, Amsterdam, }\end{array}$ & $\begin{array}{l}\text { Revised the manuscript for } \\
\text { intellectual content }\end{array}$ \\
\hline $\begin{array}{l}\text { Netherlands } \\
\text { Daniela Pohl, }\end{array}$ & $\begin{array}{l}\text { CHEO, Research } \\
\text { Institute, Ottawa, ON, } \\
\text { Canada }\end{array}$ & $\begin{array}{l}\text { Designed the study; revised } \\
\text { the manuscript for } \\
\text { intellectual content }\end{array}$ \\
\hline
\end{tabular}

\section{References}

1. Timmons M, Tsokos M, Asab MA, et al. Peripheral and central hypomyelination with hypogonadotropic hypogonadism and hypodontia. Neurology 2006;67:2066-2069.

2. Bernard G, Vanderver A. POLR3-related leukodystrophy. In: GeneReviews. Seattle, WA: University of Washington, Seattle; 2012.

3. Dorboz I, Dumay-Odelot H, Boussaid K, et al. Mutation in POLR3K causes hypomyelinating leukodystrophy and abnormal ribosomal RNA regulation. Neurol Genet 2018;4:e289. doi: 10.1212/NXG.0000000000000289.

4. Battini R, Bertelloni S, Astrea G, et al. Longitudinal follow up of a boy affected by Pol IIIrelated leukodystrophy: a detailed phenotype description. BMC Med Genet 2015;16:53.

5. Wolf NI, Vanderver A, van Spaendonk RM, et al. Clinical spectrum of $4 \mathrm{H}$ leukodystrophy caused by POLR3A and POLR3B mutations. Neurology 2014;83:1898-1905.

6. Vanderver A, Tonduti D, Bernard G, et al. More than hypomyelination in Pol-III disorder. J Neuropathol Exp Neurol 2013;72:67-75.

7. Tewari VV, Mehta R, Sreedhar CM, et al. A novel homozygous mutation in POLR3A gene causing $4 \mathrm{H}$ syndrome: a case report. BMC Pediatr 2018;18:126. 


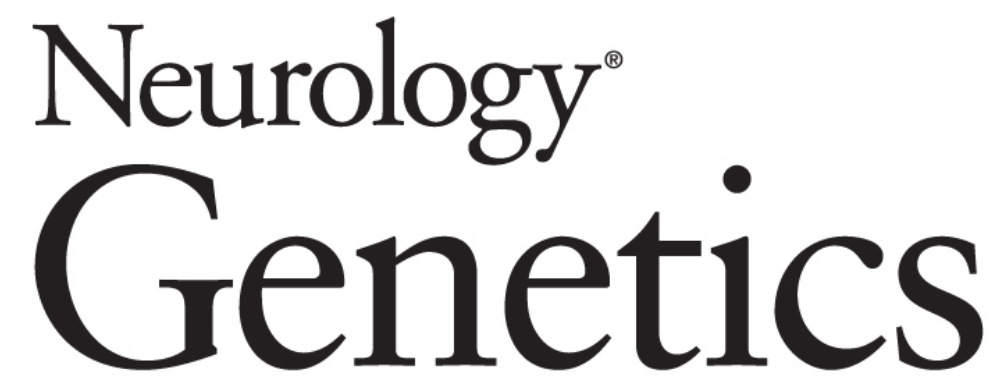

4H leukodystrophy: Mild clinical phenotype and comorbidity with multiple sclerosis Stephanie M. DeGasperis, Geneviève Bernard, Nicole I. Wolf, et al.

Neurol Genet 2020;6;

DOI 10.1212/NXG.0000000000000409

This information is current as of March 11, 2020

Neurol Genet is an official journal of the American Academy of Neurology. Published since April 2015, it is an open-access, online-only, continuous publication journal. Copyright Copyright ( 2020 The Author(s). Published by Wolters Kluwer Health, Inc. on behalf of the American Academy of Neurology.. All rights reserved. Online ISSN: 2376-7839.

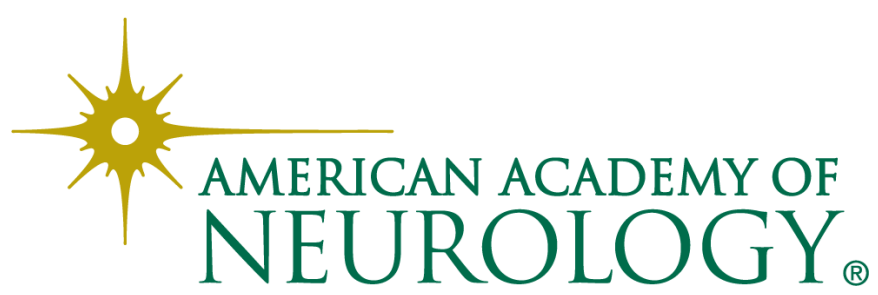




\section{Updated Information \& Services}

References

Subspecialty Collections

Permissions \& Licensing

\section{Reprints}

including high resolution figures, can be found at:

http://ng.neurology.org/content/6/2/e409.full.html

This article cites 6 articles, 1 of which you can access for free at: http://ng.neurology.org/content/6/2/e409.full.html\#\#ref-list-1

This article, along with others on similar topics, appears in the following collection(s):

All Demyelinating disease (CNS)

http://ng.neurology.org//cgi/collection/all_demyelinating_disease_cns All Epilepsy/Seizures

http://ng.neurology.org//cgi/collection/all_epilepsy_seizures

All Genetics

http://ng.neurology.org//cgi/collection/all_genetics

All Pediatric

http://ng.neurology.org//cgi/collection/all_pediatric

Leukodystrophies

http://ng.neurology.org//cgi/collection/leukodystrophies

Information about reproducing this article in parts (figures,tables) or in its entirety can be found online at:

http://ng.neurology.org/misc/about.xhtml\#permissions

Information about ordering reprints can be found online:

http://ng.neurology.org/misc/addir.xhtml\#reprintsus

Neurol Genet is an official journal of the American Academy of Neurology. Published since April 2015, it is an open-access, online-only, continuous publication journal. Copyright Copyright $\odot 2020$ The Author(s). Published by Wolters Kluwer Health, Inc. on behalf of the American Academy of Neurology.. All rights reserved. Online ISSN: 2376-7839.

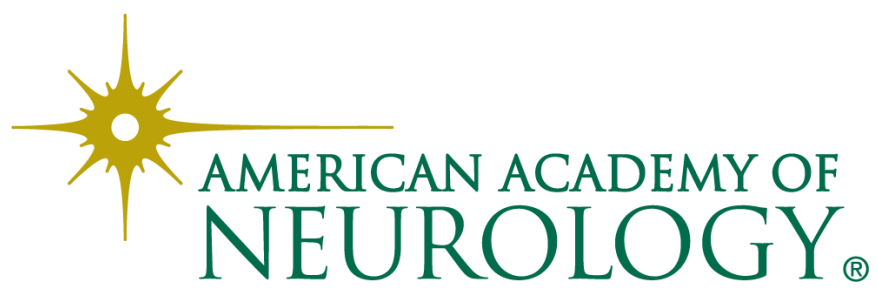

